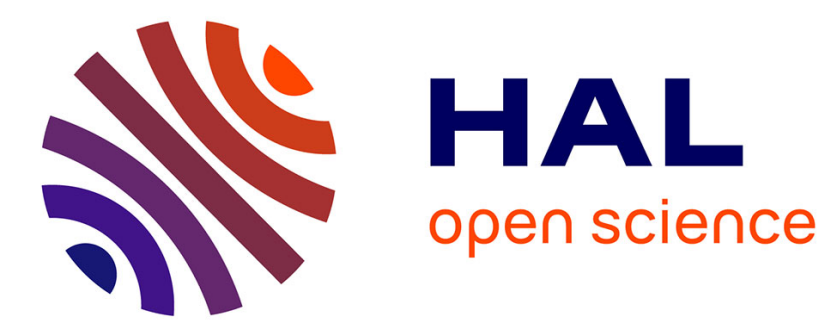

\title{
Characteristics of the Research on Reverse Logistics (1995-2005)
}

\author{
Sergio Rubio, Antonio Chamorro, Francisco Javier Miranda
}

\section{To cite this version:}

Sergio Rubio, Antonio Chamorro, Francisco Javier Miranda. Characteristics of the Research on Reverse Logistics (1995-2005). International Journal of Production Research, 2007, 46 (04), pp.10991120. 10.1080/00207540600943977 . hal-00512945

\section{HAL Id: hal-00512945 \\ https://hal.science/hal-00512945}

Submitted on 1 Sep 2010

HAL is a multi-disciplinary open access archive for the deposit and dissemination of scientific research documents, whether they are published or not. The documents may come from teaching and research institutions in France or abroad, or from public or private research centers.
L'archive ouverte pluridisciplinaire HAL, est destinée au dépôt et à la diffusion de documents scientifiques de niveau recherche, publiés ou non, émanant des établissements d'enseignement et de recherche français ou étrangers, des laboratoires publics ou privés. 


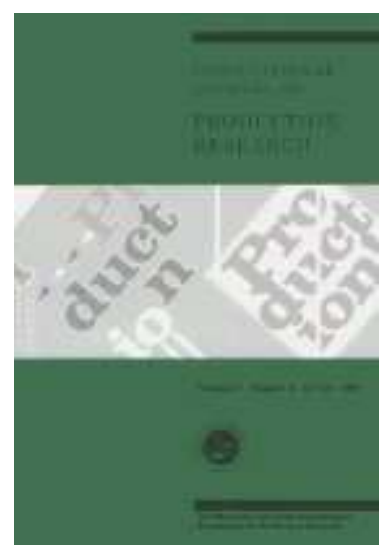

Characteristics of the Research on Reverse Logistics (19952005)

\begin{tabular}{|c|c|}
\hline Journal: & International Journal of Production Research \\
\hline Manuscript ID: & TPRS-2006-IJPR-0357.R1 \\
\hline Manuscript Type: & Original Manuscript \\
\hline $\begin{array}{r}\text { Date Submitted by the } \\
\text { Author: }\end{array}$ & 03-Aug-2006 \\
\hline Complete List of Authors: & $\begin{array}{l}\text { Rubio, Sergio; University of Extremadura, School of Industrial } \\
\text { Engineering } \\
\text { Chamorro, Antonio; University of Extremadura, Faculty of } \\
\text { Economics and Business Management } \\
\text { Miranda, Francisco; University of Extremadura, Faculty of } \\
\text { Economics and Business Management }\end{array}$ \\
\hline Keywords: & REVERSE LOGISTICS, SUPPLY CHAIN MANAGEMENT \\
\hline Keywords (user): & Product Recovery, Closed-Loop Supply Chains \\
\hline
\end{tabular}

\section{S) ScholaroNE \\ Manuscript Central}




\title{
CHARACTERISTICS OF THE RESEARCH ON
}

REVERSE LOGISTICS (1995-2005)

\author{
Sergio Rubio. ${ }^{1}$ \\ University of Extremadura. School of Industrial Engineering \\ Avenida de Elvas s/n. 06071. Badajoz (Spain). \\ Tel: +34924289600. Fax: +34924289601 \\ E-mail: srubio@unex.es
}

\author{
Antonio Chamorro. \\ University of Extremadura. Faculty of Economics and Business Management \\ Avenida de Elvas s/n. 06071. Badajoz (Spain). \\ Tel: +34924289300. Fax: +34924272509 \\ E-mail: chamorro@unex.es
}

\section{Francisco J. Miranda.}

University of Extremadura. Faculty of Economics and Business Management

Avenida de Elvas s/n. 06071. Badajoz (Spain).

Tel: +34924289300 . Fax: +34924272509

E-mail: fmiranda@unex.es

\footnotetext{
${ }^{1}$ Corresponding author
} 


\title{
CHARACTERISTICS OF THE RESEARCH ON \\ REVERSE LOGISTICS (1995-2005)
}

\begin{abstract}
This paper aims to describe and analyse the main characteristics of articles on reverse logistics published in the production and operations management field, in order to determine the evolution of this current of research over recent years and improve our understanding of this issue. We built up a database with the articles on reverse logistics published in the most relevant journals within the period 1995-2005, and we have explored the topic, the methodology and the techniques of analysis, as well as other relevant aspects of the research. We have evaluated the first decade of research on reverse logistics, observing what has been done and how, where and by whom it has been carried out. The result is an extensive review of the research works that have created and developed the reverse logistics concept, outlining some directions of research for the near future and offering practical help to those who begin to research on this topic.
\end{abstract}

Keywords: Reverse logistics; product recovery; literature review. 


\section{INTRODUCTION}

Reverse logistics is a research area that has been of particular interest to the academic community in recent years and this is reflected in the main journals on production and operations management. In view of this interest, we propose to analyse the main characteristics of these studies in order to evaluate what has been done and how, where and by whom it has been carried out. The answers to these questions will not only allow us to deepen our knowledge of the current situation of reverse logistics research, but will also help us to determine what still needs to be investigated, outlining some directions of research for the near future and offering practical help to those who begin to research on this topic. In this respect, the objective of this work is to analyse the main characteristics of a series of studies on the concept of reverse logistics that have been published in some of the most prestigious scientific journals in the period 1995-2005.

Clearly, the idea of tackling a literature analysis of this size is very ambitious and it must be appropriately delimited, so that the abundance and heterogeneity of the data available does not prevent us achieving the objectives we have set ourselves. In this respect, we should point out that we are only interested in those articles that can be considered essential points of reference in the reverse logistics field and we have therefore selected those papers published in the main international scientific journals.

The concept of reverse logistics has evolved over the years, passing through varying stages until becoming consolidated (de Brito and Dekker 2004, Fernández 2005). Among the many definitions that have been suggested for this concept (Stock 1992, Rogers and 
Tibben-Lembke 1999, Dowlatshahi 2000, among others), the proposal of the European Working Group on Reverse Logistics, REVLOG, appears to us to be the most complete and will hence be the definition that we shall use in this current work. This research group defines reverse logistics as 'the process of planning, implementing and controlling backward flows of raw materials, in process inventory, packaging and finished goods, from a manufacturing, distribution or use point, to a point of recovery or point of proper disposal' (de Brito and Dekker 2004, p.5). Given its novelty as a research area, the definition of reverse logistics may cause certain confusion among those interested in the area, with the result that it can often be confused with issues that are related to it but strictly distinct from it: industrial ecology, green supply chains, waste management, etc. To avoid any possibility of ambiguity in the delimitation of the object of our work, we shall focus on those articles that have contributed to building and developing this line of research, ignoring those that do not explicitly examine any of the elements making up the concept of reverse logistics as defined here.

Furthermore, we feel that it is necessary to analyse works of the highest quality, so that our findings lead to conclusions based on criteria of quality in the research. Thus, we have selected a group of journals of renowned prestige among the international academic community, completing the selection with other publications that are highly regarded in the area of production and operations management.

Given these premises, the rest of this paper is structured as follows: first, we describe the methodology we have employed to build the database of articles to be analysed. We then present the main research topics within the reverse logistics field 
identified in our analysis of the specialized literature. In the following section we outline the main findings of our research. We end with a section outlining our conclusions and final reflections.

\section{METHODOLOGY}

The sources of information required for the present research consist of a group of specialized journals considered likely to include works in the reverse logistics field. We have excluded proceedings and doctoral theses, in the understanding that quality studies tend to be published in this type of journal eventually and in addition these publications are the most cited in scientific papers. In this point we coincide with the majority of previous studies carried out at the international level (Stahl et al. 1988; Bairam 1994).

The next step was to select the scientific journals that would be considered in this study. We opted to select the most prestigious publications in the area of Business Management and for this we made use of the list of journals published by ISI Journal of Citation Reports (2004). Among the various topics used by this classification, we chose the subject categories 'Business', 'Management' and 'Operations Research and Management Science', which we felt would be the most likely to include journals publishing works on the concept of reverse logistics. Obviously, not all articles on reverse logistics published during the period of analysis would have been published in impact factor journals. There are other prestigious scientific publications not included in the ISI Journal of Citation Reports that have published articles on this topic and we feel they should be included in our work in order to lend more significance to the findings that we obtain and also to be able to 
more accurately observe the evolution in the research on reverse logistics in the past decade. On the other hand, these journals are included in other studies analyzing the state of the research in the field of production and operations management (Babbar and Prasad 1998; Barman et al. 2001; Prasad et al. 2001).

For the present study, we ignore brief notes, introductions, editorials, professional commentaries and book reviews, which are common in the journals analysed and which cannot be classified as published articles. We have however opted to include articles appearing in monographic editions on Supply Chain Management and the Environment, since although these may distort the results somewhat because of their focus on a specific subject, we believe they reflect the interest of researchers on the topic that is object of study here, as well as the need to advance understanding in it.

Our analysis relates to the period 1995-2005, since although there are articles centring on this issue prior to 1995 (among which, Guiltinan and Nwokoye 1975, Fuller 1978, Ginter and Starling 1978), and even two monographs (Stock 1992, Kopicki et al. 1993), it is really only after this year that the concept of reverse logistics itself becomes consolidated and we start to see works on the environmental aspects of Supply Chain Management finding space in this type of journal (Alfaro et al. 2003). Moreover, to the best of our knowledge, there are not articles on reverse logistics published in journals included in JCR, before this year.

As we pointed out earlier, our idea was to analyse those articles that study aspects directly related to reverse logistics. With this in mind, we carried out a literature search 
using the terms 'reverse logistics' and/or 'product recovery' in the title, abstract or keywords of the articles appearing in the selected journals during the period of analysis. The inclusion of the term 'product recovery' is justified because in a first search where we included only the concept 'reverse logistics', we found that an important number of works were absent, works that were relevant in spite of not containing the term 'reverse logistics'. This term has become consolidated only gradually, in parallel with the growing appearance of research papers on the topic in these journals. In any case, each work resulting from the search was then carefully analysed in order to confirm that its focus was indeed on reverse logistics. Furthermore, we examined the bibliography of each article to detect potential omissions from the initial search and finally we compared the resulting database with the set of bibliographical references used in various monographs (Fleischmann 2001, Dekker et al. 2004, Dyckhoff et al. 2004). Thus, we completed our database, which contained a total of 186 articles published in 26 journals (see Table 1). A total of $68.28 \%$ of the articles were published in journals edited in Europe and the remaining $31.72 \%$ in publications from the United States. However, half of the journals included in this study have been edited in USA and the other half in Europe,

Once we had built up our database we analysed each article using a data collection sheet in which we included, among other things, information concerning the research topic in which the article was framed, the methodology followed, the techniques of analysis employed, the number of authors, their origin and the number of references used. Moreover, in cases where it was relevant, we examined, complementary aspects of the 
research such as the information collection techniques, sources of information employed, the temporal and geographical scope of the study and the unit of analysis utilized.

Table 1. List of journals

\begin{tabular}{|c|c|}
\hline Journal & Articles \\
\hline California Management Review & 10 \\
\hline Computers \& Industrial Engineering & 9 \\
\hline Computers \& Operations Research & 1 \\
\hline European Journal of Operational Research & 24 \\
\hline Harvard Business Review & 2 \\
\hline IEEE Transactions on Engineering Management & 1 \\
\hline IIE Transactions & 5 \\
\hline Industrial Marketing Management & 2 \\
\hline Interfaces & 11 \\
\hline International Journal of Physical Distribution \& Logistics Management & 10 \\
\hline International Journal of Production Economics & 29 \\
\hline International Journal of Production Research & 25 \\
\hline International Journal of Technology Management & 1 \\
\hline Journal of Operations Management & 4 \\
\hline Journal of Retailing & 1 \\
\hline Journal of the Operational Research Society & 8 \\
\hline Management Science & 7 \\
\hline Naval Research Logistics & 2 \\
\hline 20 & 3 \\
\hline Operations Research & 1 \\
\hline OR Spectrum & 11 \\
\hline Production and Operations Management & 7 \\
\hline Production Planning \& Control & 5 \\
\hline Technological Forecasting and Social Change & 1 \\
\hline Total Quality Management \& Business Excellence & 1 \\
\hline Transportation Research Part E: Logistics and Transportation Review & 5 \\
\hline TOTAL & 186 \\
\hline
\end{tabular}


In order to determine the main research topics in the reverse logistics field, we considered it advisable to use the classification employed by Dekker et al. (2004), who identify three fundamental areas of research on reverse logistics:

1) Management of the recovery and distribution of end-of-life products

2) Production planning and inventory management

3) Supply chain management issues in reverse logistics

Within the first research topic, 'management of the recovery and distribution of endof-life products', we find all those works analysing the different physical flows present in the reverse logistics systems, especially those issues relating to the collection and distribution of end-of-life (EOL) products. Thus, aspects such as the analysis of EOL product returns, the design of the reverse logistics network and its interaction with the forward logistics flow, the analysis of transport routes or questions of internal logistics, among others, are covered by this research topic. The topic 'production planning and inventory management' embraces those works in which the main object of the research is the coordination of the processes of EOL product recovery and particularly aspects deriving from the existence of a reverse flow of EOL products and its interaction with traditional production planning. Among the main questions analysed by the studies in this topic, we find: the effects that the existence of a reverse flow of EOL products generates in the traditional models of inventory management, the dynamic capabilities of these reverse 
flows, specific aspects of planning production such as the design of disassembly operations and the coordination of manufacturing operations with economic recovery operations (remanufacturing, recycling, reuse). Finally, the topic 'supply chain management issues in reverse logistics' concerns those works that analyse the strategic decisions, which the existence of a reverse flow of EOL products generates in the management of the supply chain. Thus, questions such as the long-term behaviour of closed-loop supply chains, the role of IT, the impact of environmental regulation and the environmental management of reverse logistics, among others, are included in this topic.

We classified the articles within each research topic by examining the title, abstract, keywords and main body of the paper. This review was carried out independently by each member of the research team. Most of the articles were classified unequivocally into one of the three different topics. However $14.75 \%$ of them were either considered doubtful or two or more members of the team disagreed in their classifications. In these cases, we reviewed the articles again and then the team as a whole agreed on the most appropriate classification.

\section{RESULTS}

In the first place, we observe that reverse logistics, as a research area in the field of production and operations management, has experienced increasing interest in the period of analysis considered, a fact that is mainly reflected in the growth in the number of articles published in the journals analysed (figure 1). 
One of the reasons for this spectacular growth is found in the monographs and special issues that various journals have dedicated to environmental questions associated with production and operations management. In fact, in 1999 Computers \& Industrial Engineering dedicated an edition to the analysis of manufacturing processes that were respectful to the environment (Environmentally Conscious Manufacturing); in the year 2000, Interfaces published a monograph under the title 'Sustainable Business'; in 2001, OR Spectrum and Production and Operations Management published issues on 'Operational Research and Environmental Management' and 'Environmental Management and Operations', respectively; in late 2003, Interfaces published another special edition, on this occasion on the problems thrown up by closed-loop supply chains. Finally, in 2004, California Management Review edited a special issue on 'Closed-loop Supply Chains Management'. Throughout 2006 more special issues on reverse logistics will be published: Omega on 'Reverse production systems', International Journal of Production Economics on 'Sustainable supply chain management', OR Spectrum on 'Product recovery' and Production and Operations Management on 'Closed-loop supply chains'. In addition to these special editions, in recent years various monographs on reverse logistics have been published: Stock (1998), Fleischmann (2001), Guide and Van Wassenhove (2003), Dekker et al. (2004) and Dyckhoff et al. (2004). Thus, we can clearly say that the interest of the academic community in this research topic has grown significantly in recent years, which has consequently contributed to its development, both quantitatively and qualitatively. 
Figure 1. Number of articles published in the period

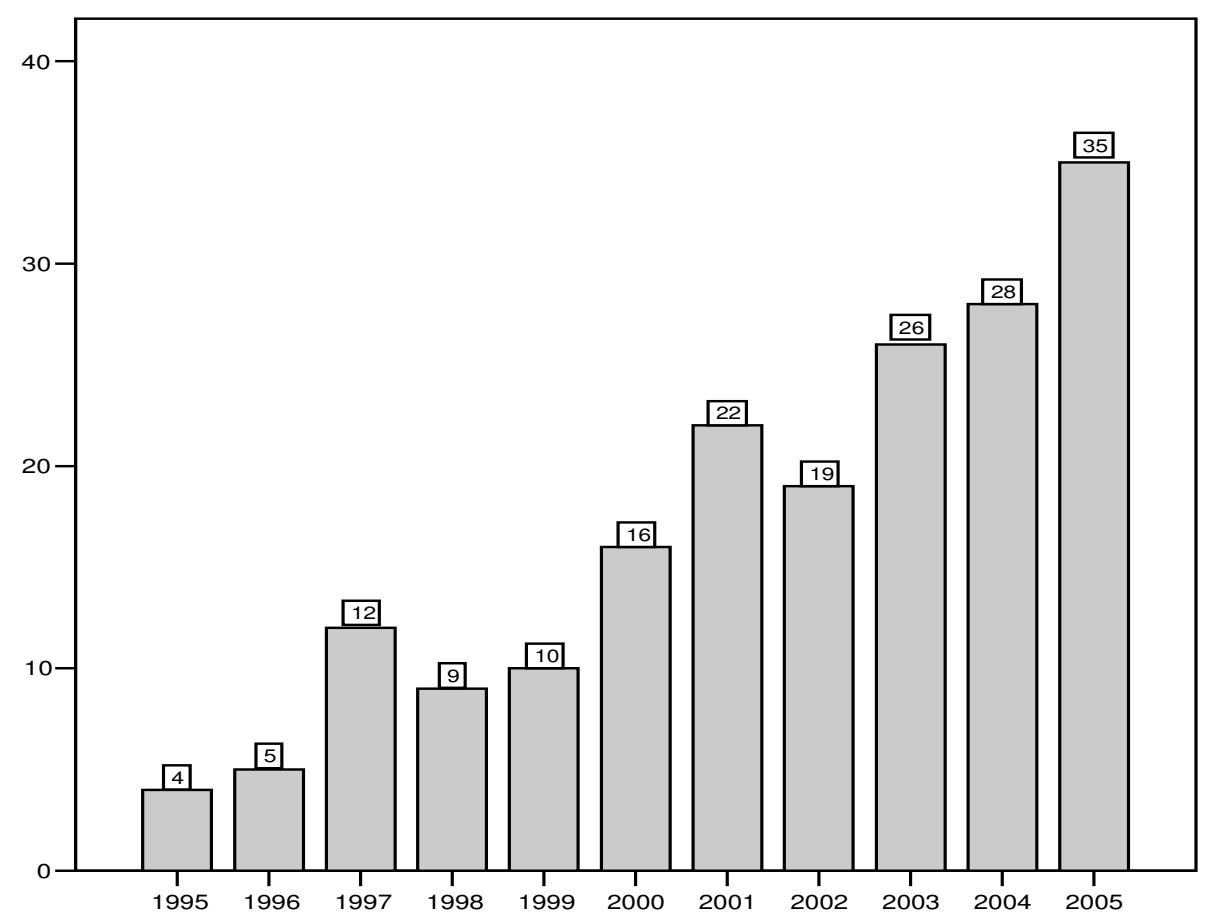

Analysing the articles by research topic, we observe that $56.45 \%$ can be included within the topic 'production planning and inventory management', $31.18 \%$ analyse questions of a strategic nature and can be framed within the topic 'supply chain management issues in reverse logistics', while $12.37 \%$ of the articles analyse questions relating to the 'management of the recovery and distribution of end-of-life products'. However, we note that the topic 'supply chain management issues in reverse logistics' has attracted the attention of researchers in recent years. In fact, most of the works published in 2004 and 2005 fall within that research topic (figure 2). 
Figure 2. Evolution of Research Topics

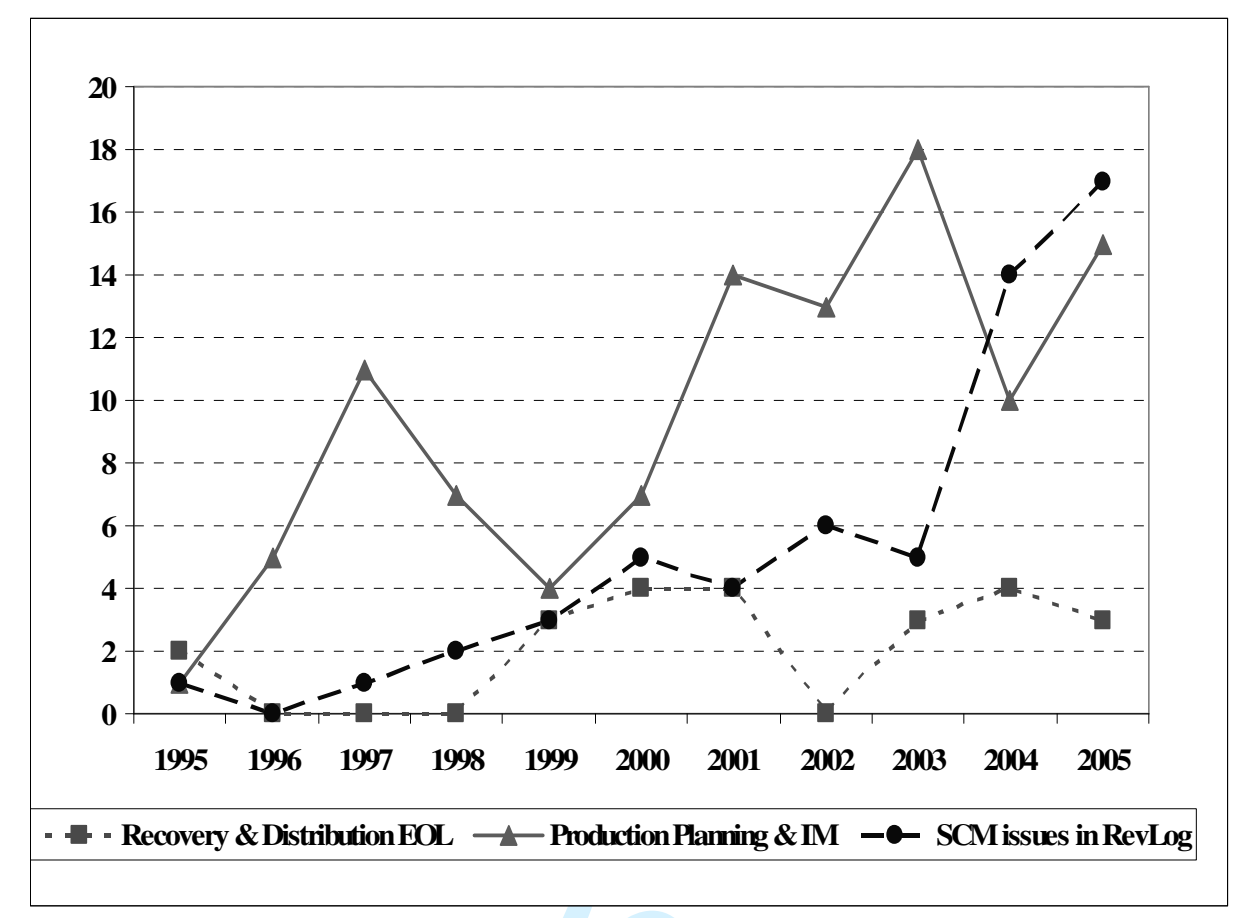

The studies published during the period of analysis appear to be focusing on the analysis of tactical and operational decisions, a finding which should have some relation with the type of study carried out as well as the methodology followed. In this respect, the analysed works employ methodologies (figure 3) that are both quantitative (basically using mathematical models) and qualitative (case study, literature review or theoretical developments). A total of $19.89 \%$ of the articles analysed use two different research methodologies, with case studies being the most popular of the second methodologies chosen $(54.05 \%)$. 
Figure 3. Research methodology

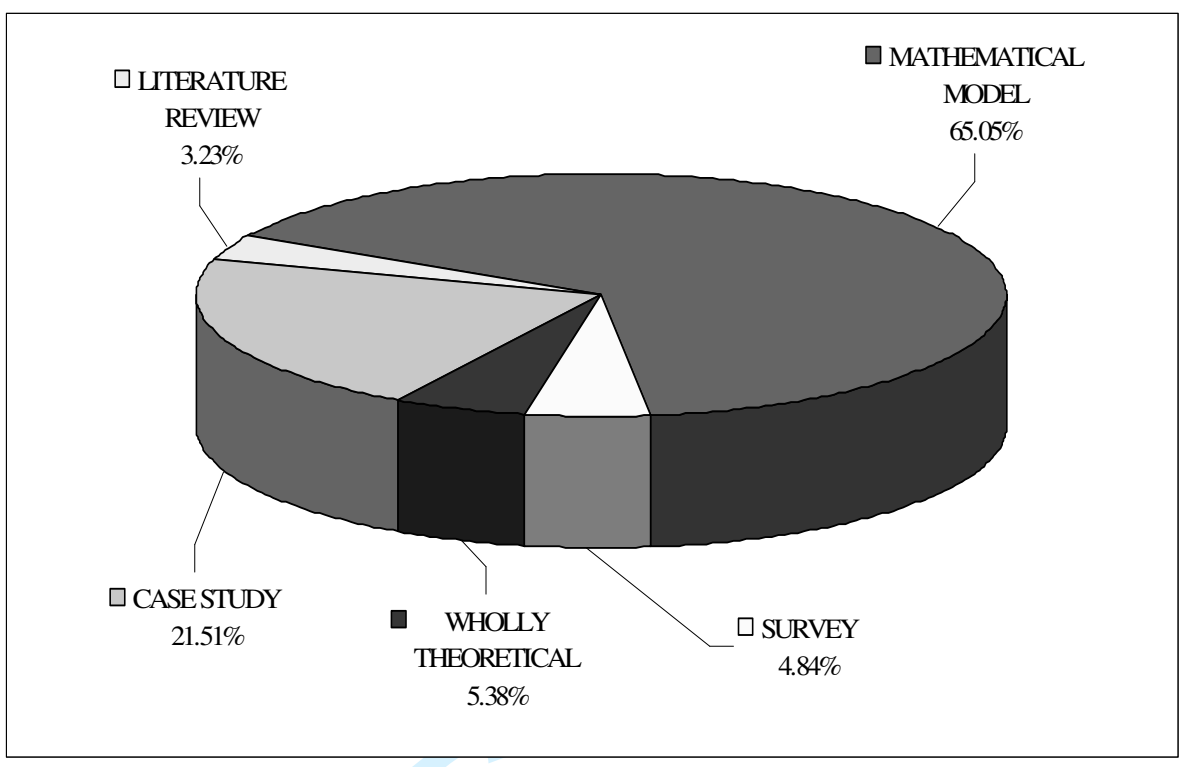

With regards to the relation between the research topic and the journal in which the article appears (table 3), we find that $60.87 \%$ of the articles analysing the 'management of the recovery and distribution of end-of-life products' are concentrated in just four journals: Computers \& Industrial Engineering, Interfaces, International Journal of Production Research and OR Spectrum. Furthermore, all of the articles on this topic are published in just ten of the analysed journals. In turn, the works on 'production planning and inventory management' are published in a wider spread of journals. Indeed we find only seven publications that have not published articles on this research topic in the period of analysis. In any case, the European journals European Journal of Operational Research, International Journal of Production Economics and International Journal of Production Research published fully $57.14 \%$ of the articles on this topic. With regards to 'supply chain management issues in reverse logistics', we find that twenty of the analysed journals 


\begin{tabular}{|c|c|c|c|c|c|c|c|}
\hline \multirow{2}{*}{$\begin{array}{c}\text { JOURNAL } \\
\text { CALIF MANAGE REV }\end{array}$} & \multicolumn{2}{|c|}{$\begin{array}{c}\text { Management of the recovery } \\
\text { and distribution of EOL } \\
\text { products }\end{array}$} & \multicolumn{2}{|c|}{$\begin{array}{l}\text { Production planning and } \\
\text { inventory management }\end{array}$} & \multicolumn{2}{|c|}{$\begin{array}{l}\text { Supply chain management } \\
\text { issues in reverse logistics }\end{array}$} & \multirow{2}{*}{$\begin{array}{c}\text { TOTAL } \\
10 \\
\end{array}$} \\
\hline & $\mathbf{0}$ & $0.00 \%$ & $\mathbf{0}$ & $0.00 \%$ & 10 & $17.24 \%$ & \\
\hline COMPUT IND ENG & 3 & $13.04 \%$ & 4 & $3.81 \%$ & 2 & $3.45 \%$ & 9 \\
\hline COMPUT OPER RES & $\mathbf{0}$ & $0.00 \%$ & $\mathbf{1}$ & $0.95 \%$ & $\mathbf{0}$ & $0.00 \%$ & 1 \\
\hline EUR J OPER RES & 2 & $8.70 \%$ & 17 & $16.19 \%$ & 5 & $8.62 \%$ & 24 \\
\hline HARVARD BUS REV & $\mathbf{0}$ & $0.00 \%$ & $\mathbf{0}$ & $0.00 \%$ & 2 & $3.45 \%$ & 2 \\
\hline IEEE TENG MANAGE & $\mathbf{0}$ & $0.00 \%$ & $\mathbf{1}$ & $0.95 \%$ & $\mathbf{0}$ & $0.00 \%$ & 1 \\
\hline IIE TRANS & $\mathbf{0}$ & $0.00 \%$ & 5 & $4.76 \%$ & $\mathbf{0}$ & $0.00 \%$ & 5 \\
\hline IND MARKET MANAG & $\mathbf{0}$ & $0.00 \%$ & $\mathbf{0}$ & $0.00 \%$ & 2 & $3.45 \%$ & 2 \\
\hline INTERFACES & 4 & $17.39 \%$ & 2 & $1.90 \%$ & 5 & $8.62 \%$ & 11 \\
\hline IJPD\&LM & 2 & $8.70 \%$ & $\mathbf{1}$ & $0.95 \%$ & 7 & $12.07 \%$ & 10 \\
\hline INT J PROD ECON & $\mathbf{0}$ & $0.00 \%$ & 25 & $23.81 \%$ & 4 & $6.90 \%$ & 29 \\
\hline INT J PROD RES & 3 & $13.04 \%$ & 18 & $17.14 \%$ & 4 & $6.90 \%$ & 25 \\
\hline INT J TECHNOL MANAGE & $\mathbf{0}$ & $0.00 \%$ & $\mathbf{0}$ & $0.00 \%$ & 1 & $1.72 \%$ & 1 \\
\hline J OPER MANAG & $\mathbf{0}$ & $0.00 \%$ & 4 & $3.81 \%$ & $\mathbf{0}$ & $0.00 \%$ & 4 \\
\hline J RETAILING & $\mathbf{0}$ & $0.00 \%$ & $\mathbf{0}$ & $0.00 \%$ & 1 & $1.72 \%$ & 1 \\
\hline J OPER RES SOC & $\mathbf{0}$ & $0.00 \%$ & 6 & $5.71 \%$ & 2 & $3.45 \%$ & 8 \\
\hline MANAGE SCI & $\mathbf{1}$ & $4.35 \%$ & 5 & $4.76 \%$ & $\mathbf{1}$ & $1.72 \%$ & 7 \\
\hline NAVRES LOG & $\mathbf{0}$ & $0.00 \%$ & 2 & $1.90 \%$ & $\mathbf{0}$ & $0.00 \%$ & 2 \\
\hline OMEGA-INT J MANAGE S & $\mathbf{1}$ & $4.35 \%$ & $\mathbf{1}$ & $0.95 \%$ & $\mathbf{1}$ & $1.72 \%$ & 3 \\
\hline OPER RES & $\mathbf{0}$ & $0.00 \%$ & $\mathbf{1}$ & $0.95 \%$ & $\mathbf{0}$ & $0.00 \%$ & 1 \\
\hline OR SPECTRUM & 4 & $17.39 \%$ & 6 & $5.71 \%$ & $\mathbf{1}$ & $1.72 \%$ & 11 \\
\hline PROD OPER MANAG & 2 & $8.70 \%$ & 3 & $2.86 \%$ & 2 & $3.45 \%$ & 7 \\
\hline PROD PLAN CONTROL & $\mathbf{1}$ & $4.35 \%$ & 2 & $1.90 \%$ & 2 & $3.45 \%$ & 5 \\
\hline TECHNOL FORECAST SOC & $\mathbf{0}$ & $0.00 \%$ & $\mathbf{0}$ & $0.00 \%$ & $\mathbf{1}$ & $1.72 \%$ & 1 \\
\hline TOTAL QUAL MANAG BUS & $\mathbf{0}$ & $0.00 \%$ & $\mathbf{0}$ & $0.00 \%$ & $\mathbf{1}$ & $1.72 \%$ & 1 \\
\hline TRANSPORT RES E-LOG & $\mathbf{0}$ & $0.00 \%$ & $\mathbf{1}$ & $0.95 \%$ & 4 & $6.90 \%$ & 5 \\
\hline TOTAL & 23 & $12.37 \%$ & 105 & $56.45 \%$ & 58 & $31.18 \%$ & 186 \\
\hline
\end{tabular}

\section{Table 3. Journal and Research Topic}

include works on this topic, with a similar level of concentration, since $67.24 \%$ of the works were published in a group of seven journals: California Management Review, European Journal of Operational Research, Interfaces, International Journal of Physical Distribution \& Logistics Management, International Journal of Production Economic, European Journal of Production Research and Transportation Research, Part E. 
Table 4. Articles by topic and methodology

\begin{tabular}{|c|c|c|c|c|c|c|c|c|c|}
\hline & \multicolumn{2}{|c|}{ CASE STUDY } & \multirow{2}{*}{\begin{tabular}{||c|} 
LITERATURE REVIEW \\
Fleischmann et al., 2000
\end{tabular}} & \multicolumn{4}{|c|}{ MATHEMATICAL MODEL } & \multirow{2}{*}{\begin{tabular}{|c|}
\multicolumn{1}{|c|}{ SURVEY } \\
Guide Jr. \& Jayaraman, 2000 \\
\end{tabular}} & \multirow[t]{2}{*}{ WHOLLY TEORETICAL } \\
\hline $\begin{array}{l}\text { MANAGEMENT OF } \\
\text { THE RECOVERY AND } \\
\text { DISTRIBUTION OF } \\
\text { EOL PRODUCTS }\end{array}$ & \begin{tabular}{|c|} 
Guide Jr. \& Van Wassenhove, 2001 \\
Guide J. et al., 2005 \\
Jahre, 1995 \\
Klausner \& Hendrickson, 2000 \\
Krikke et al., 1999a \\
Krikke et al., 1999b \\
\end{tabular} & $\begin{array}{l}\text { Kroon \& Vrijens, } 1995 \\
\text { le Blanc et al., } 2004 \\
\text { Listes \& Dekker, } 2005 \\
\text { Ravi et al., } 2005 \\
\text { Rudi et al., } 2000 \\
\text { Schultmann et al., } 2003 \\
\end{array}$ & & & $\begin{array}{c}\text { Baumgarten et al., } 2004 \\
\text { Beamon \& Fernandes, } 2004 \\
\text { Dethloff, 2001 } \\
\text { Fleischmann et al., } 2001 \\
\text { Jarayaman et al., } 2003 \\
\end{array}$ & $\begin{array}{c}\text { Krikke et al., } 2003 \\
\text { Lowers et al., } 1999 \\
\text { Savaskan et al., } 2004 \\
\text { Sodhi \& Reimer, } 2001\end{array}$ & & & \\
\hline $\begin{array}{c}\text { PRODUCTION } \\
\text { PLANNING AND } \\
\text { INVENTORY } \\
\text { MANAGEMENT }\end{array}$ & $\begin{aligned} \text { de Brito \& Dekl } \\
\text { Ferrer \& Whyba } \\
\text { Ferrer, } 20 \\
\text { Guide Ir. et al } \\
\text { Kekre et al., } \\
\text { Linton \& Johst } \\
\text { Spengler et al }\end{aligned}$ & $\begin{array}{l}\text { ker, } 2003 \\
\text { ark, } 2001 \\
\text { o, } \\
1,2003 \\
2003 \\
\text { ton, } 2000 \\
\text {.., } 1997\end{array}$ & Guide Jr., 2000 & 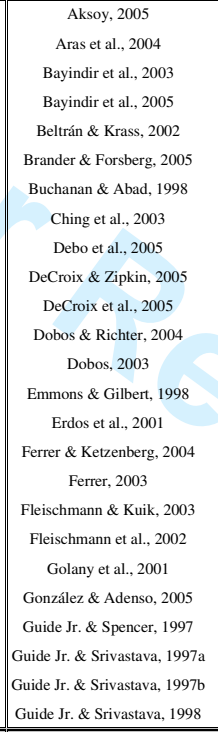 & 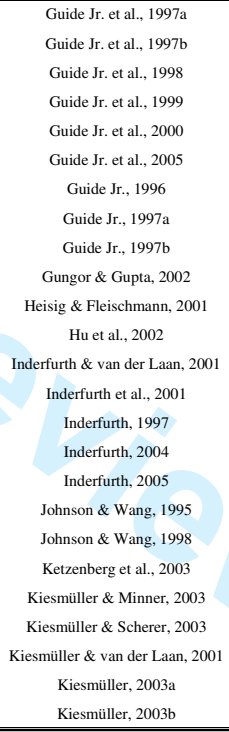 & 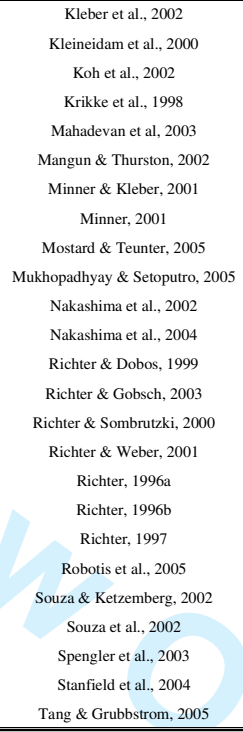 & 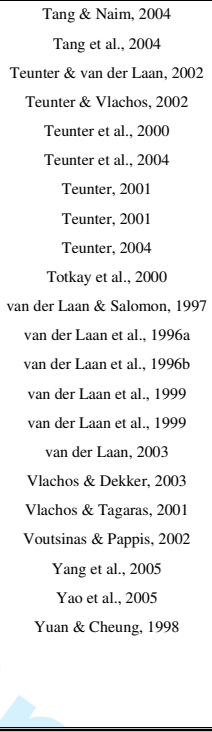 & & \\
\hline $\begin{array}{c}\text { SUPPLY CHAIN } \\
\text { MANAGEMENT } \\
\text { ISSUES IN REVERSE } \\
\text { LOGISTICS }\end{array}$ & $\begin{array}{c}\text { Amini et all, } 2005 \\
\text { Barros te tal., } 1998 \\
\text { Dhanda \& Hill, } 2005 \\
\text { Dowlatshahi, } 2005 \\
\text { Ferguson \& Browne, } 2001 \\
\text { Fleischmann et al, } 2003 \\
\text { Geyer \& Jackson, } 2004 \\
\text { Goggin et al., } 2000 \\
\text { Goldsby \& Closss, } 2000 \\
\text { Hicks et al., } 2004 \\
\text { Johnson, } 1998 \\
\end{array}$ & \begin{tabular}{|c||} 
Krikke et al., 2004 \\
Maslennikova \& Foley, 2000 \\
Matthews, 2004 \\
Nagel \& Meyer, 1999 \\
Seitz \& Peattie, 2004 \\
Spengler \& Schröter, 2003 \\
Tan et al., 2003 \\
Thierry et al., 1995 \\
Tibben-Lembe, \\
van Nunen \& Zuidwijk, 2004 \\
\end{tabular} & $\begin{array}{c}\text { Fleischmann et al., } 1997 \\
\text { Gungor \& Gupta, } 1999 \\
\text { Kleindorfer et al., } 2005 \\
\text { Tibben-Lembke, } 2002\end{array}$ & & $\begin{array}{l}\text { Bufardi et al., } 2004 \\
\text { Fandel \& Stammen, } 2004 \\
\text { Freire et al., } 2001 \\
\text { Georgiadis \& Vlachos, } 2004 \\
\text { Heese et al., } 2005 \\
\text { Horvath et al., } 2005 \\
\text { Jarayaman et al., } 1999 \\
\text { Linton et al., } 2002\end{array}$ & $\begin{array}{l}\text { Majumuder \& Groenevelt, } 2001 \\
\text { Naguuney \& Toyakasi, } 2005 \\
\text { Okumura et al., 2003 } \\
\text { Ravi \& Shankar, 2005 } \\
\text { Sheu et al., 2005 } \\
\text { Walther \& Spengler, 2005 } \\
\text { Yalabiik et al., 2005 }\end{array}$ & & \begin{tabular}{|c|} 
Autry et al., 2001 \\
Autry, 2005 \\
Daugherty et al., 2005 \\
Gonzźlez-Torre et al., 2004 \\
Knemeyer et al., 2002 \\
Kulp et al., 2004 \\
Richey et al., 2005a \\
Richey et al., 2005b
\end{tabular} & \begin{tabular}{||c|} 
Blackburn et al., 2004 \\
Dowlatshahi, 2000 \\
Fassoula, 2005 \\
Guide Jr. \& Van Wassenhove, 2002 \\
Guide Jr. et al., 2000 \\
Krumwiede \& Sheu, 2002 \\
Linton \& Jarayaman, 2005 \\
Stock et al., 2002 \\
Toffel, 2004 \\
Tofffel, 2003 \\
\end{tabular} \\
\hline
\end{tabular}

http://mc.manuscriptcentral.com/tprs Email: ijpr@lboro.ac.uk 
As far as the methodology employed in the articles is concerned, we grouped the articles by research topic and examined the main methodology in order to determine if there were correspondences between the topic and the methodology (table 5). From our findings, we observe a clear association between the topic 'production planning and inventory management' and mathematical modelling as a methodology of analysis (fundamentally operational research and control theory techniques). The works on 'supply chain management issues in reverse logistics', in coherence with its strategic focus, tend to employ qualitative methodologies such as the case study, conceptual descriptions and the literature review. However, at the same time as this topic expands, it can be seen that there has been a trend to use mathematical models in recent years. For its part, 'management of the recovery and distribution of end-of-life products' is in an intermediate position between the quantitative and qualitative methodologies, which could point to a more homogeneous development of this research topic, insofar as it analyses the strategic aspects by means of qualitative methodologies (56.52\%) and the tactical and operational decisions utilizing quantitative techniques and methods.

Table 5. Research topic and Methodology

\begin{tabular}{|c|c|c|c|c|c|c|}
\hline & \multicolumn{5}{|c|}{ METHODOLOGY } & \multirow[b]{2}{*}{ TOTAL } \\
\hline & CASE STUDY & $\begin{array}{c}\text { LITERATURE } \\
\text { REVIEW }\end{array}$ & $\begin{array}{c}\text { MATHEMATICAL } \\
\text { MODEL }\end{array}$ & SURVEY & $\begin{array}{c}\text { WHOLLY } \\
\text { THEORETICAL }\end{array}$ & \\
\hline $\begin{array}{c}\text { MANAGEMENT OF THE RECOVERY } \\
\text { AND DISTRIBUTION OF EOL } \\
\text { PRODUCTS } \\
\end{array}$ & $52.17 \%$ & $4.35 \%$ & $39.13 \%$ & $4.35 \%$ & $0.00 \%$ & $12.37 \%$ \\
\hline $\begin{array}{l}\text { PRODUCTION PLANNING AND } \\
\text { INVENTORY MANAGEMENT }\end{array}$ & $6.67 \%$ & $0.95 \%$ & $92.38 \%$ & $0.00 \%$ & $0.00 \%$ & $\mathbf{5 6 . 4 5 \%}$ \\
\hline $\begin{array}{l}\text { SUPPLY CHAIN MANAGEMENT } \\
\text { ISSUES IN REVERSE LOGISTICS }\end{array}$ & $36.21 \%$ & $6.90 \%$ & $25.86 \%$ & $13.79 \%$ & $17.24 \%$ & $31.18 \%$ \\
\hline TOTAL & $21.51 \%$ & $3.23 \%$ & $65.05 \%$ & $4.84 \%$ & $5.38 \%$ & \\
\hline
\end{tabular}


When studying the main techniques employed for the data analysis (table 6), we find that mathematical programming techniques are the most used in the group of articles as a whole $(18.58 \%)$, these mainly been used for the analysis of the problems arising in the 'management of the recovery and distribution of end-of-life products'. We should bear in mind that this topic includes problems of allocation and localization - traditionally formulated and solved using linear programming. For their part, the works dealing with 'supply chain management issues in reverse logistics' prefer to employ descriptive analysis and the case study, in coherence with the qualitative methodology that predominates in these studies. Finally, we observe that simulation, together with mathematical programming, optimization and queueing, are the most common analytical techniques within the topic 'production planning and inventory management', as would be expected in these works that analyse the effect that the reverse flow of EOL products has on models of inventory management.

Table 6. Techniques employed for the data analysis

\begin{tabular}{|c|c|c|c|c|c|c|c|c|}
\cline { 2 - 9 } \multicolumn{2}{|c|}{} & \multicolumn{7}{c|}{ TECHNIQUE OF ANALYSIS } \\
\hline RESEARCH TOPIC & Case Analysis & Control Theory & $\begin{array}{c}\text { Descriptive } \\
\text { Analysis }\end{array}$ & $\begin{array}{c}\text { Mathematical } \\
\text { Programming }\end{array}$ & Optimization & $\begin{array}{c}\text { Queueing and } \\
\text { Markov Process }\end{array}$ & Simulation & Others \\
\hline $\begin{array}{c}\text { Management of the recovery } \\
\text { and distribution of EOL } \\
\text { products }\end{array}$ & $30.43 \%$ & $0.00 \%$ & $8.70 \%$ & $43.48 \%$ & $4.35 \%$ & $0.00 \%$ & $4.35 \%$ & $8.70 \%$ \\
\hline $\begin{array}{c}\text { Product planning and } \\
\text { inventory management }\end{array}$ & $4.76 \%$ & $9.52 \%$ & $1.90 \%$ & $16.19 \%$ & $16.19 \%$ & $16.19 \%$ & $20.95 \%$ & $14.29 \%$ \\
\hline $\begin{array}{c}\text { Supply chain management } \\
\text { issues in Reverse Logistics }\end{array}$ & $27.59 \%$ & $0.00 \%$ & $29.31 \%$ & $12.07 \%$ & $3.45 \%$ & $1.72 \%$ & $6.90 \%$ & $18.97 \%$ \\
\hline TOTAL & $\mathbf{1 5 . 3 0 \%}$ & $\mathbf{5 . 4 6 \%}$ & $\mathbf{1 1 . 4 8 \%}$ & $\mathbf{1 8 . 5 8 \%}$ & $\mathbf{1 0 . 9 3 \%}$ & $\mathbf{9 . 8 4 \%}$ & $\mathbf{1 4 . 7 5 \%}$ & $\mathbf{1 3 . 6 6 \%}$ \\
\hline
\end{tabular}


As far as the number of authors of each article is concerned, we observe that collaboration between researchers is predominant, since $83.87 \%$ of the works have two or more authors: specifically, $37.10 \%$ of the articles are signed by two, $35.48 \%$ by three and $11.29 \%$ by four or more authors.

With regards to the origin of the publications analysed, these are mostly concentrated in just three countries: USA (31.72\%), the Netherlands (16.67\%) and Germany (11.29\%). In addition, $22.58 \%$ of the works have authors of different origins, although in $64.29 \%$ of these cases the first signer belongs to a research centre located in one of the three above-mentioned countries. Thus, we can say that research on reverse logistics is concentrated in research centres of these countries, or at least we observe a clear influence of them in work on this topic.

We find that $93.7 \%$ of the works are authored by members of the academic community, while the remaining $4.3 \%$ have authors who are professionals in the business or industrial world. However, these works are fundamentally collaborations between firms and the university, and only two of the articles analysed (Maslennikova and Foley 2000, Fassoula 2005) are authored exclusively by researchers with no links to a university. With respect to the articles with university origins, we find that the Erasmus University Rotterdam (the Netherlands) is the main focus of research, since $15.59 \%$ of the analysed articles have a member of this university as first signer. In fact we find 57 instances of authors connected to this university in the total number of articles selected. At a significant distance comes the Duquesne University (USA), Air Force Institute of Technology (USA) and Otto-von-Guericke University (Germany), each of which has 3.76\% of the first signers. 
Finally, we should point out that the Erasmus University Rotterdam is the main research centre in the reverse logistics field also from the point of view of the three research topics analysed, since scholars connected to this university first-signed $26.09 \%$ of the articles on 'management of the recovery and distribution of end-of-life products', 17.14\% of the works analysing 'production planning and inventory management' and $8.62 \%$ of the articles on 'supply chain management issues in reverse logistics'.

\section{CONCLUSIONS}

Throughout this work, we have analysed the development of research on reverse logistics over the recent years, by examining the scientific articles appearing in the main international specialized journals in the field of production and operations management. Our main goal has been to analyse the evolution and basic characteristics of the research on this topic, so that we could observe the path followed up to the present time, describe the current situation of the research and provide ideas about where it could be directed in the future. In accordance with our findings, we can point out the following conclusions:

- Although there were some earlier works focusing on issues related to reverse logistics, this current of research is very recent - its origins can effectively be dated to 1995 . Since then, researchers have become increasingly interested in the field, as demonstrated by the progressive growth in the number of articles on the topic published (especially from 2000) and the appearance of numerous monographs in the journals. In general terms, the data on the number of publications confirms the growing interest of both the academic and professional communities in the relations 
between the firm and the environment (Hoffman and Ehrenfeld 1998, Burgos and Céspedes 2001).

- The majority of articles centre on the study of tactical and operational aspects like production planning and inventory management, deriving from the implementation of a reverse logistics system. However, we observe that issues regarding closedloop supply chain management have received the preferred attention of researchers in recent years, although we consider that more research on strategic factors (marketing, competition, technology) seems necessary in order to develop a theoretical framework for research.

- In our analysis of the association between topic and the methodology and research techniques used, we find a 'typical profile' for articles and research topic. Research on 'management of the recovery and distribution of end-of-life products' is characterized by using indistinctively both quantitative and qualitative techniques, applying mathematical models and the case study as main methodologies. Research on 'production planning and inventory management', in accord with its quantitative profile, tends to be analytical in content and favours techniques such as simulation, optimization and mathematical programming. Regarding research on 'supply chain management issues in reverse logistics', this was characterized by being mainly theoretical and qualitative, largely using the case study, although a quantitative trend has been detected in recent years.

- Research on reverse logistics has been led by scholars from the Netherlands, Germany and the USA. The first two of these countries have a strong environmental 
tradition, both in legislative terms and with respect to the concerns of their societies, while the US is characterized by its liberal returns policy. Both features have provided an incentive for the research on reverse logistics, thereby contributing to its development. Nevertheless, it would be necessary to expand the research to the supply chains of others countries, especially the emerging and transition economies which will play a leading role in the global supply chain in the next years.

To conclude, we should stress again that our initial intention was to analyse the main characteristics of the research in the reverse logistics field, an ambitious task interacting with many other fields of research within business management, engineering and the environmental sciences. The problems have extensive ramifications; there are various ways of approaching them and many aspects to clarify. All of these will have to be analysed in future works. In this respect, we feel that research on reverse logistics should now be directed at analysing strategic aspects and developing organizational theories, allowing us to establish an appropriate framework of reference within which the tactical and operational aspects that have been analysed in recent years can be developed efficiently. 


\section{REFERENCES}

Aksoy, H. K. And Gupta, S. M., Buffer allocation plan for a remanufacturing cell. Computers \& Indust. Eng., 2005, 48, 657-677.

Alfaro, J. A., Álvarez, M. J., Montes, M. J. and Viguier, R., Gestión de la cadena de suministros y medio ambiente: Interrelación y líneas de investigación conjuntas, in XIII Congreso Nacional de ACEDE, 2003.

Amini, M. M., Retzlaff-Roberts, D. and Bienstock, C., Designing a reverse logistics operation for short cycle time repair services. Int. J. Prod. Econ., 2005, 96, 367-380.

Aras, N., Boyaci, T. and Verter, V., The effect of categorizing returned products in remanufacturing. IIE Transactions, 2004, 36, 319-331.

Autry, C. W., Daugherty, P. J. and Richey, R. G., The challenge of reverse logistics in catalog retailing. Int. J. Phys. Dist. \& Logist. Manage., 2001, 31, 26-37.

Autry, C. W., Formalization of reverse logistics programs: A strategy for managing liberalized returns. Ind. Market. Manage., 2005, 34, 749-757.

Babbar, S. and Prasad, S., International purchasing, inventory management and logistics research: an assessment and agenda. Int. J. Op. \& Prod. Manage., 1998, 18, 6-36.

Bairam, E. I., Institutional affiliation of contributors to top economic journals, 1985-1990. J. Econ. Literature, 1994, 32, 674-679.

Barman, S., M. Hanna, D. and Laforge R. L., Perceived relevance and quality of POM journals: a decade later. J. Op. Manage., 2001, 19, 367-385.

Barros, A. I., Dekker, R. and Scholten, V., A two-level network for recycling sand: a case study. Euro. J. Op. Res., 1998, 110, 199-214. 
Baumgarten, H., Klinker, R. and Sommer-Dittrich, T., Reconfigurable logistics systems in production and disassembly networks. Int. J. Prod. Res., 2004, 42, 3647-3655.

Bayindir, Z. P., Erkip, N. and Güllü, R., Assessing the benefits of remanufacturing option under one-way substitution. J. Op. Res. Soc., 2005, 56, 286-296.

Beamon, B. M. and Fernandes, C., Supply-chain network configuration for product recovery. Prod. Planning \& Control, 2004, 13, 270-281.

Blackburn, J. D., Guide, Jr., V. D. R., Souza, G. C. and Van Wassenhove, L. N., Reverse supply chains for commercial returns. California Manage. Rev., 2004, 46, 6-22.

Brander, P. and Forsberg, R., Cyclic lot scheduling with sequence-dependent set-ups: a heuristic for disassembly processes. Int. J. Prod. Res., 2005, 43, 295-310.

Bufardi, A., Gheorghe, R., Kiritsis, D. and Xirouchakis, P., Multicriteria decision-aid approach for product end-of-life alternative selection. Int. J. Prod. Res., 2004, 42, 3139-31547.

Burgos, J. and Céspedes, J. J., Environmental performance as operations objective. Int. J. Op. \& Prod. Manage., 2001, 21, 1553-1572.

Ching, W. K., Yuen, W. O. and Loh, A. W., An inventory model with returns and lateral transhipments. J. Op. Res. Soc., 2003, 54, 636-641.

Daugherty, P. J., Richey, R. G., Genchev, S. E. and Chen, H., Reverse logistics: superior performance through focused resource commitments to information technology. Trans. Res., Part E, Logist. Trans. Rev., 2005, 41, 77-92.

De Brito, M. and Dekker, R., A framework for reverse logistics. In Reverse Logistics. Quantitative models for closed-loop supply chains, edited by Dekker, R., 
Fleischmann, M., Inderfurth K. and Van Wassenhove, L. N., 2004, 3-27. (SpringerVerlag, Germany)

De Brito, M. and Dekker, R., Modelling products return in inventory control: exploring the validity of general assumptions. Int. J. Prod. Econ., 2003, 81-82, 225-241.

Debo, L. G., Totkay, L. B. and Van Wassenhove, L. N., Market segmentation and product technology selection for remanufacturable products. Manage. Sci., 2005, 51, 11931205.

DeCroix, G. and Zipkin, P., Inventory management for an assembly system with product or component returns. Manage. Sci., 2005, 51, 1250-1265.

DeCroix, G., Song, J. S. and Zipkin, P., A series system with returns: Stationary analysis. Oper. Res., 2005, 53, 350-362.

Dekker, R., Fleischmann, M., Inderfurth K. and Van Wassenhove, L. N. (Eds.) Reverse Logistics: Quantitative models for closed-loop supply chains. 2004. (SpringerVerlag, Germany)

Dethloff, J., Vehicle routing and reverse logistics: The vehicle routing problem with simultaneous delivery and pick-up. OR Spectrum, 2001, 23, 79-96.

Dhanda, K. K. and Hill, R. P., The role of information technology and systems in reverse logistics: a case study. Int. J. Technol. Manage., 2005, 31, 140-151.

Dobos, I. and Richter, K., An extended production/recycling model with stationary demand and return rates. Int. J. Prod. Econ., 2004, 90, 311-323.

Dobos, I., Optimal production-inventory strategies for a HMMS-type reverse logistics system. Int. J. Prod. Econ., 2003, 81-82, 351-360. 
Dowlatshahi, S., A strategic framework for the design and implementation of remanufacturing operations in reverse logistics. Int. J. Prod. Res., 2005, 43, 34553480.

Dowlatshahi, S., Developing a reverse logistics theory, Interfaces, 2000, 30, 143-155.

Dyckhoff, H., Lackes R. and Reese, J. (Eds.), Supply chain management and reverse logistics. 2004. (Springer-Verlag, Germany)

Emmons, H., and Gilbert S. M., The role of return policies pricing and inventory decisions for catalogue goods. Manage. Sci., 1998, 44, 276-283.

Erdos, G., Kis, T. and Xirouchakis, P., Modelling and evaluating product end-of-life options. Int. J. Prod. Res., 2001, 39, 1203-1220.

Fassoula, E. D., Reverse logistics as a means of reducing the cost of quality. Total Qual. Manag. Bus., 2005, 16, 631-643.

Ferguson, N. and Browne J., Issues in end-of-life product recovery and reverse logistics. Prod. Planning \& Control, 2001, 12, 534-547.

Fernández , I., Análisis de la logística inversa en el entorno empresarial. Una aproximación cualitativa. 2005. (Universidad de Oviedo, Spain).

Ferrer, G. and Ketzenberg, M .E., Value of information in remanufacturing complex product. IIE Transactions, 2004, 36, 265-277.

Ferrer, G. and Whybark, D. C., Material planning for a remanufacturing facility. Prod. \& Op. Manage., 2001, 10, 112-124.

Ferrer, G., On the widget remanufacturing operation. Euro. J. Op. Res., 2001, 135, 373393. 
Fleischmann, M. and Kuik, R., On optimal inventory control with independent stochastic item returns. Euro. J. Op. Res., 2003, 151, 25-37.

Fleischmann, M., Beullens, P., Bloemhof-Ruwaard, J. M. and Van Wassenhove, L. N., The impact of product recovery on logistics network. Prod. \& Op. Manage., 2001, 10, $156-173$.

Fleischmann, M., Bloemhof-Ruwaard, J. M., Dekker, R., Van der Laan, E. A., Van Nunen, J. A. E. E. and Van Wassenhove, L. N., Quantitative models for reverse logistics: a review. Euro. J. Op. Res., 1997, 103, 1-13.

Fleischmann, M., Krikke, H. R., Dekker, R. and Flapper, S. P. D, A characterisation of logistics networks for product recovery. Omega, 2000, 28, 653-666.

Fleischmann, M., Kuik, R. and Dekker, R., Controlling inventories with stochastic item returns: A basic model. Euro. J. Op. Res., 2002, 138, 63-75.

Fleischmann, M., Quantitative models for reverse logistics. 2001. (Springer-Verlag, Germany)

Fleischmann, M., Van Nunen, J. A. E. E. and Gräve, B., Integrating closed-loop supply chains and spare-parts management at IBM. Interfaces, 2003, 33, 44-56.

Freire, F., Thore, S. and Ferrao, P., Life cycle activity analysis: logistics and environmental policies for bottled water in Portugal. OR Spectrum, 2001, 23, 159-182.

Fuller, D.A., Recycling consumer solid waste: a commentary on selected channel alternatives. J. Business Res., 1978, 6, 17-31.

Georgiadis, P. and Vlachos, D., The effect of environmental parameters on product recovery. Euro. J. Op. Res., 2004, 157, 449-464. 
Geyer, R. and Jackson, T., Supply loops and their constraints. The industrial ecology of recycling and reuse. California Manage. Rev., 2004, 46, 55-73.

Ginter, P. M. and Starling, J. M., Reverse distribution channels for recycling. California Manage. Rev., 1978, 20, 73-82.

Goggin, K., Reay, E. and Browne, J., Modelling end-of-life recovery chains: a case study. Prod. Planning \& Control, 2000, 11, 87-196.

Golany, B., Yang, J. and Yu, G., Economic lot-sizing with remanufacturing options. IIE Transactions, 2001, 33, 995-1003.

Goldsby, T. J. and Closs, D. J., Using activity-based costing to reengineer the reverse logistics channel. Int. J. Phys. Distrib. \& Logist. Manage., 2000, 30, 500-514.

González, B. and Adenso-Díaz, B., A bill of materials-based approach for end-of-life decision making in design for the environment. Int. J. Prod. Res., 2005, 43, 20712099.

González-Torre, P. L., Adenso-Díaz, B. and Artiba, H., Environmental and reverse logistics policies in European bottling and packaging firms. Int. J. Prod. Econ., 2004, 88, 95104.

Guide Jr., V. D. R. and Jayaraman, V., Product acquisition management: current industry practice and proposed framework. Int. J. Prod. Res., 2000, 38, 3779-3808.

Guide Jr., V. D. R. and Spencer, M. S., Rough-cut capacity planning for remanufacturing firms. Prod. Planning \& Control, 1997, 8, 237-244.

Guide Jr., V. D. R. and Srivastava, R., Buffering from material recovery uncertainty in a recoverable manufacturing environment. J. Op. Res. Soc., 1997a, 48, 519-529. 
Guide Jr., V. D. R. and Srivastava, R., Repairable inventory theory: Models and applications. Euro. J. Op. Res., 1997b, 102, 1-20.

Guide Jr., V. D. R. and Srivastava, R., Inventory buffers in recoverable manufacturing. J. Op. Manage., 1998, 16, 551-568.

Guide Jr., V. D. R. and Van Wassenhove, L. N., Business aspects of closed-loop supply chains. 2003, (Carnegie Mellon University Press, Pittsburgh, PA)

Guide Jr., V. D. R. and Van Wassenhove, L. N., Managing product returns for remanufacturing. Prod. \& Op. Manage., 2001, 10, 142-155.

Guide Jr., V. D. R. and Van Wassenhove, L. N., The reverse supply chain. Harvard Business Review, 2002, 80, 25-27.

Guide Jr., V. D. R., Jarayaman, V., Srivastava, R. and Benton, W. C., Supply-chain management for recoverable manufacturing systems. Interfaces, 2000, 30, 125-142.

Guide Jr., V. D. R., Jayaraman, V. and Srivastava, R., The effect of lead time variation on the performance of disassembly release mechanisms. Computers \& Indust. Eng., 1999, 36, 759-779.

Guide Jr., V. D. R., Kraus, M. E. and Srivastava, R., Scheduling policies for remanufacturing. Int. J. Prod. Econ., 1997, 48, 187-204.

Guide Jr., V. D. R., Muyldermans, L., and Van Wassenhove, L. N., Hewlett-Packard company unlocks the value potential from time-sensitive returns. Interfaces, 2005 , 35, 281-293.

Guide Jr., V. D. R., Production planning and control for remanufacturing: industry practice and research needs. J. Op. Manage., 2000, 18, 467-483. 
Guide Jr., V. D. R., Scheduling using drum-buffer-rope in a remanufacturing environment. Int. J. Prod. Res., 1996, 34, 1081-1091.

Guide Jr., V. D. R., Scheduling with priority dispatching rules and drum-buffer-ropes in a recoverable manufacturing system. Int. J. Prod. Econ., 1997, 53, 101-116.

Guide Jr., V. D. R., Souza, G. C. and van der Laan, E., Performance of static priority rules for shared facilities in a remanufacturing shop with disassembly and reassembly. Euro. J. Op. Res., 2005, 164, 341-353.

Guide Jr., V. D. R., Srivastava, R. and Kraus, M. E., Priority scheduling policies for repair shops. Int. J. Prod. Res., 2000, 38, 929-950.

Guide Jr., V. D. R., Srivastava, R. and Kraus, M. E., Proactive expediting policies for recoverable manufacturing. J. Op. Res. Soc., 1998, 49, 479-491.

Guide Jr., V. D. R., Srivastava, R. and Kraus, M. E., Product structure complexity and scheduling of operations in recoverable manufacturing. Int. J. Prod. Res., 1997, 35, 3179-3199.

Guide Jr., V. D. R., Srivastava, R. and Spencer, M. S., An evaluation of capacity planning techniques in a remanufacturing environment. Int. J. Prod. Res., 1997, 35, 67-82.

Guide, Jr., V. D. R., Jayaraman, V. and Linton, J. D., Building contingency planning for closed-loop supply chains with product recovery. J. Op. Manage., 2003, 21, 259279.

Guiltinan, J. P., and Nwokoye, N. G., Developing distribution channels and systems in the emerging recycling industry. Int. J. Phys. Distrib., 1975, 1, 28-38.

Gungor, A. and Gupta, S. M., Disassembly line in product recovery. Int. J. Prod. Res., 2002, 40, 2569-2589. 
Gungor, A. and Gupta, S. M., Issues in environmentally conscious manufacturing and recovery products: a survey. Computers \& Indust. Eng., 1999, 36, 811-853.

Heese, H. S., Cattani, K., Ferrer, G., Gilland, W. and Roth, A. V., Competitive advantage through take-back of used products. Euro. J. Op. Res., 2005, 164, 143-157.

Heisig, G. and Fleischmann, M., Planning stability in a product recovery system. $O R$ Spectrum, 2001, 23, 25-50.

Hicks, C., Heidrich, O., McGovern, T. and Donnelly, T., A functional model of supply chains and waste. Int. J. Prod. Econ., 2004, 89, 165-174.

Hoffman, A. and Ehrenfeld, J., Corporate environmentalism and management studies. In Environmental Strategies for Industry: The Future of Corporate Practice, edited by Roome, N., 1998, 55-73. (Island Press, Washington DC)

Horvath, P. A., Autry, C. W. and Wilcox, W. E., Liquidity implications of reverse logistics for retailers: A Markov chain approach. J. Retailing, 2005, 81, 191-203.

Hu, T. L., Sheu, J. B. and Huang, K. H., A reverse logistics cost minimization model for the treatment of hazardous wastes. Trans. Res., Part E, Logist. Trans. Rev., 2002, 38, 457-473.

Inderfurth, K. and Van der Laan, E., Lead-time effects and policy improvement for stochastic inventory control with remanufacturing. Int. J. Prod. Econ., 2001, 71, pp. 381-390.

Inderfurth, K., De Kok, A. G. and Flapper, S. D. P., Product recovery in stochastic remanufacturing system with multiple reuse options. Euro. J. Op. Res., 2001, 133, $130-152$.

http://mc.manuscriptcentral.com/tprs Email: ijpr@lboro.ac.uk 
Inderfurth, K., Impact of uncertainties on recovery behavior in a remanufacturing environment: A numerical analysis. Int. J. Phys. Distrib. \& Logist. Manage., 2005, 35, 318-336.

Inderfurth, K., Optimal policies in hybrid manufacturing/remanufacturing systems with product substitution. Int. J. Prod. Econ., 2004, 90, 325-343.

Inderfurth, K., Simple optimal replenishment and disposal policies for a product recovery system with lead-times. OR Spectrum, 1997, 19, 111-122.

Jahre, M., Household waste collection as a reverse channel: A theoretical perspective. Int. J. Phys. Distrib. \& Logist. Manage., 1995, 25, 39-55.

Jarayaman, V., Patterson, R. A. and Rolland, E., The design of reverse distribution networks: Models and solution procedures. Euro. J. Op. Res., 2003, 150, 128-149.

Jayaraman, V., Guide Jr., V. D. R. and Srivastava, R., A closed-loop logistics model for remanufacturing. J. Op. Res. Soc., 1999, 50, 497-508.

Johnson, M. R. and Wang, M. H., Economical evaluation of disassembly operations for recycling, remanufacturing and reuse. Int. J. Prod. Res., 1998, 36, 3227-3252.

Johnson, M. R. and Wang, M. H., Planning product disassembly for material recovery opportunities. Int. J. Prod. Res., 1995, 33, 3119-3142.

Johnson, P. F., Managing value in reverse logistics systems. Trans. Res., Part E, Logist. Trans. Rev., 1998, 34, 217-227.

Kekre, S., Rao, U. S., Swaminathan, J. and Zhang, J., Reconfiguring a remanufacturing line at Visteon, Mexico. Interfaces, 2003, 33, 30-43.

Ketzenberg, M. E., Souza, G. C. and Guide Jr., V. D. R., Mixed assembly and disassembly operations for remanufacturing. Prod. \& Op. Manage., 2003, 12, 320-335. 
Kiesmüller, G. P. and Minner, S., Simple expressions for finding recovery systems inventory control parameter values. J. Op. Res. Soc., 2003, 54, 83-88.

Kiesmüller, G. P. and Van der Laan, E., An inventory model with dependent product demands and returns', Int. J. Prod. Econ., 2001, 72, 73-87.

Kiesmüller, G. P., A new approach for controlling a hybrid stochastic manufacturing/remanufacturing system with inventories and different lead-times. Euro. J. Op. Res., 2003a, 147, 62-71.

Kiesmüller, G. P., and Scheder, C. W., Computational issues in a stochastic finite horizon one product recovery inventory model. Euro. J. Op. Res., 2003, 146, 553-579.

Kiesmüller, G. P., Optimal control of a one product recovery system with lead-times. Int. J. Prod. Econ., 2003b, 81-82, 333-340.

Klausner, M. and Hendrickson, C. T., Reverse logistics strategy for product take-back. Interfaces, 2000, 30, 156-165.

Kleber, R., Minner, S. and Kiesmüller, G. P., A continuous time inventory model for a product recovery system with multiple options. Int. J. Prod. Econ., 2002, 79, 121141.

Kleindorfer, P. R., Sighal, K. and Van Wassenhove, L. N., Sustainable operations management. Prod. \& Op. Manage., 2005, 14, 482-492.

Kleineidam, U., Lambert, A. J. D., Blansjaar, J., Kok, J. J. and Van Heijningen, R. J. J., Optimising product recycling chains by control theory. Int. J. Prod. Econ., 2000, 66, 185-195. 
Knemeyer, A. M., Ponzurick, T. G. and Logar, C. M., A qualitative examination of factors affecting reverse logistics systems for end-of-life computers. Int. J. Phys. Distrib. \& Logist. Manage., 2002, 32, 455-479.

Koh, S. G., Hwang, H., Sohn, K. I. and Ko , C. S., An optimal ordering and recovery policy for reusable items. Computers \& Indust. Eng., 2002, 43, 59-73.

Kopicky, R. J., Berg, M. J., Legg, L., Dasappa, V. and Maggioni, C., Reuse and Recycling: Reverse Logistics Opportunities. 1993, (Council of Logistics Management, Oak Brook, IL)

Krikke, H. R., Bloemhof-Ruwaard, J. and Van Wassenhove, L. N., Concurrent product and closed-loop supply chain design with an application to refrigerators. Int. J. Prod. Res., 2003, 41, 3689-3719.

Krikke, H. R., Van Harten, A. and Schuur, P. C., Business case Océ: Reverse logistic network re-design for copiers. OR Spectrum, 1999b, 21, 381-409.

Krikke, H. R., Van Harten, A. and Schuur, P. C., Business case Roteb: recovery strategies for monitors. Computers \& Indust. Eng., 1999a, 36, 739-757.

Krikke, H. R., Van Harten, A. and Schuur, P. C., On a medium term product recovery and disposal strategy for durable assembly products. Int. J. Prod. Res., 1998, 36, 111139.

Krikke, H., Le Blanc, I. and Van De Velde, S., Product modularity and the design of closed-loop supply chains. California Manage. Rev., 2004, 46, 23-39.

Kroon, L. and Vrijens, G., Returnable containers: an example of reverse logistics. Int. J. Phys. Distrib. \& Logist. Manage., 1995, 25, 56-68. 
Krumwiede, D. W. and Sheu C., A model for reverse logistics entry by third-party providers. Omega, 2002, 30, 325, 333.

Kulp, S. C., Lee, H. L. and Ofek, E., Manufacturer benefits from information integration with retail customers. Manage. Sci., 2004, 50, 431-444.

Le Blanc, H. M., Fleuren, H. A. and Krikke, H. R., Redesign of a recycling system for LPG-tanks. OR-Spectrum, 2004, 26, 286-304.

Linton, J. D. and Jarayaman, V., A framework for identifying differences and similarities in the managerial competencies associated with different modes of product life extension. Int. J. Prod. Res., 2005, 43, 1807-1829.

Linton, J. D. and Johnston, D. A., A decision support system for planning remanufacturing at Nortel Networks. Interfaces, 2000, 30, 17-31.

Linton, J. D., Yeomans, J. S. and Yoogalingam, R., Supply planning for industrial ecology and remanufacturing under uncertainty: a numerical study of leaded-waste recovery from television disposal. J. Op. Res. Soc., 2002, 53, 1185-1196.

Listes, O. and Dekker, R., A stochastic approach to a case study for product recovery network design. Euro. J. Op. Res., 2005, 160, 268-287.

Louwers D., Kip, B. J., Peters, E., Souren, F. and Flapper, S. D. P., A facility location allocation for reusing carpet materials. Computers \& Indust. Eng., 1999, 36, 855869.

Mahadevan, B., Pyke, D. F. and Fleischmann, M., Periodic review, push inventory policies for remanufacturing. Euro. J. Op. Res., 2003, 151, 536-551.

Majumder, P. and Groenevelt, H., Competition in remanufacturing. Prod. \& Op. Manage., 2001, 10, 125-141. 
Mangun, D. and Thurston, D. L., Incorporating component reuse, remanufacture and recycle into product portfolio design. IEEE Trans. Eng. Manage., 2002, 49, 479490.

Maslennikova, I. and Foley, D., Xerox’s approach to sustainability. Interfaces, 2000, 30, 226-233.

Matthews, H. S., Thinking outside 'the box': designing a packaging take-back system. California Manage. Rev., 2004, 46, 105-119.

Minner, S. and Kleber, R., Optimal control of production and remanufacturing in a simple recovery model with linear cost functions. OR Spectrum, 2001, 23, 3-24.

Minner, S., Strategic safety stocks in reverse logistics supply chains. Int. J. Prod. Econ., 2001, 71, 417-428.

Mostard, J. and Teunter, R., The newsboy problem with resalable returns: A single period model and case study. Euro. J. Op. Res., 2005, 169, 81-96.

Mukhopadhyay, S. K. and Setoputro, R., Optimal return policy and modular design for build-to-order products. J. Op. Manage., 2005, 23, 496-506.

Nagel, C. and Meyer P., Caught between ecology and economy: end-of-life aspects of environmentally conscious manufacturing. Computers \& Indust. Eng., 1999, 36, 781-792.

Nagurney, A. and Toyasaki, F., Reverse supply chain management and electronic waste recycling: a multitiered network equilibrium framework for e-cycling. Trans. Res., Part E, Logist. Trans. Rev., 2005, 41, 1-28.

Nakashima, K., Arimitsu, H., Nose, T. and Kuriyama, S., Analysis of a product recovery system. Int. J. Prod. Res., 2002, 40, 3849-3856. 
Nakashima, K., Arimitsu, H., Nose, T. and Kuriyama, S., Optimal control of a remanufacturing system. Int. J. Prod. Res., 2004, 42, 3619-3625.

Okumura, S., Morikuni, T. and Okino, N., Environmental effects of physical life span of a reusable unit following functional and physical failures in a remanufacturing system. Int. J. Prod. Res., 2003, 41, 3667-3687.

Prasad, S., Babbar, S. and Motwani, J., International operations strategy: current efforts and future directions. Int. J. Op. \& Prod. Manage., 2001, 21, 645-655.

Ravi, V. and Shankar, R., Analysis of interactions among the barriers of reverse logistics. Technol. Forecast. Soc., 2005, 72, 1011-1029.

Ravi, V., Shankar, R. and Tiwari, M. K., Analyzing alternatives in reverse logistics for endof-life computers: ANP and balanced scorecard approach. Computers \& Indust. Eng., 2005, 48, 327-356.

Richey, R. G., Chen, H., Genchev, S. E. and Daugherty, P. J., Developing effective reverse logistics programs. Ind. Market. Manage., 2005, 34, 830-840.

Richey, R. G., Genchev, S. E. and Daugherty, P. J., The role of resource commitment and innovation in reverse logistics performance. Int. J. Phys. Distrib. \& Logist. Manage., 2005, 35, 233-257.

Richter K. and Jens, W., The reverse Wagner-Whitin model with variable manufacturing and remanufacturing cost. Int. J. Prod. Econ., 2001, 71, 447-456.

Richter, K. and Sombrutzki, M., Remanufacturing planning for the reverse Wagner-Whitin models. Euro. J. Op. Res., 2000, 121, 304-315.

Richter, K. The extended EOQ repair and waste disposal model. Int. J. Prod. Econ., 1996b, 45, 443-447. 
Richter, K., Pure and mixed strategies for the EOQ repair and waste disposal problem. OR Spectrum, 1997, 19, 123-129.

Richter, K., The EOQ and waste disposal model with variable setups numbers. Euro. J. Op. Res., 1996a, 95, 313-324.

Robotis, A., Bhattacharya, S. and Van Wassenhove, L. N., The effect of remanufacturing on procurement decisions for resellers in secondary markets. Euro. J. Op. Res., 2005, 163, 688-705.

Rogers, D. S., and Tibben-Lembke, R. S., Going backwards: Reverse logistics trends and practice, 1999, (Reverse Logistics Executive Council, Pittsburgh, PA)

Rudi, N., Pyke, D. F. and Sporsheim, P. O., Product recovery at the Norwegian National Insurance Administration. Interfaces, 2000, 30, 166-179.

Savaskan, R. C., Bhattacharya, S. and Van Wassenhove, L. N., Closed-loop supply chain models with product remanufacturing. Manage. Sci., 2004, 50, 239-252.

Schultmann, F., Engels, B. and Rentz, O., Closed-loop supply chains for spent batteries. Interfaces, 2003, 33, 57-71.

Seitz, M. A. and Peattie, K., Meeting the closed-loop challenge: the case of remanufacturing. California Manage. Rev., 2004, 46, 74-89.

Sheu, J. B., Chou, Y. H. and Hu, C. C., An integrated logistics operational model for greensupply chain management. Trans. Res., Part E, Logist. Trans. Rev., 2005, 41, 287313.

Sodhi, M. S. and Reimer, B., Models for recycling electronics end-of-life products. OR Spectrum, 2001, 23, 97-115. 
Souza, G. C. and Ketzenberg, M. E., Two-stage market-to-order remanufacturing with service level constraints. Int. J. Prod. Res., 2002, 40, 477-493.

Souza, G. C., Ketzenberg, M. E. and Guide, Jr., V. D. R., Capacitated remanufacturing with service level constraints. Prod. \& Op. Manage., 2002, 11, 231-248.

Spengler, T., and Schröter, M., Strategic management of spare parts in closed-loop supply system: A system dynamic approach. Interfaces, 2003, 33, 7-17.

Spengler, T., Ploog, M. and Schröter, M., Integrated planning of acquisition, disassembly and bulk recycling: a case study on electronic scrap recovery. OR Spectrum, 2003, 25, 413-442.

Spengler, T., Püchert, H., Penkuhm, T. and Rentz, O., Environmental integrated production and recycling management. Euro. J. Op. Res., 1997, 97, 308-326.

Stahl, M. J., Leap, T. L. and Wei, Z. Z., Publications in leading management journals as a measure of institutional research productivity. Academy Manage. J., 1988, 31, 700720.

Stanfield, P. M., Wilson, J. R. and King, R. E., Flexible modelling of correlated operations with application in product-reuse facilities. Int. J. Prod. Res., 2004, 42, 2179-2196.

Stock, J. R., Development and implementation of reverse logistics programs, 1998, (Council of Logistics Management, Oak Brook, IL)

Stock, J. R., Reverse Logistics, 1992, (Council of Logistics Management, Oak Brook, IL)

Stock, J. R., Speh, T. and Shear, H., Many happy (product) returns. Harvard Business Review, 2002, 80, 16-17. 
Tan, A. W. K., Yu, W. S. and Arun, K., Improving the performance of a computer company in supporting its reverse logistics operations in the Asia-Pacific region. Int. J. Phys. Distrib. \& Logist. Manage., 2003, 33, 59-74.

Tang, O. and Grubbström, R. W., Considering stochastic lead times in a manufacturing/remanufacturing system with deterministic demands and returns. Int. J. Prod. Econ., 2005, 93-94, 285-300.

Tang, O. and Naim, M. N., The impact of information transparency on the dynamic behaviour of a hybrid manufacturing/remanufacturing system. Int. J. Prod. Res., 2004, 42, 4135-4152.

Tang, O., Grubbström, R. W. and Zanoni, S., Economic evaluation of disassembly processes in remanufacturing systems. Int. J. Prod. Res., 2004, 42, 3603-3617.

Teunter, R. H. and Van der Laan, E., On the non-optimality of the average cost approach for inventory models with remanufacturing. Int. J. Prod. Econ., 2002, 79, 67-73.

Teunter, R. H. and Vlachos, D., On the necessity of a disposal option for returned items that can be remanufactured. Int. J. Prod. Econ., 2002, 75, 257-266.

Teunter, R. H., A reverse logistics valuation method for inventory control. Int. J. Prod. Res., 2001a, 39, 2023-2035.

Teunter, R. H., Economic ordering quantities for recoverable item inventory systems. Naval Research Logistics, 2001b, 48, 484-495.

Teunter, R. H., Lot-sizing for inventory systems with product recovery. Computers \& Indust. Eng., 2004, 46, 431-441.

Teunter, R. H., Van der Laan, E. and Inderfurth, K., How to set the holding cost rates in average cost inventory models with reverse logistics? Omega, 2000, 28, 409-415. 
Teunter, R., Van Der Laan, E. and Vlachos, D., Inventory strategies for systems with fast remanufacturing. J. Op. Res. Soc., 2004, 55, 475-484.

Thierry, M. C., Salomon, M., Van Nunen, J. A. E. E. and Van Wassenhove, L. N., Strategic issues in product recovery management. California Manage. Rev., 1995, 37, 114135.

Tibben-Lembke, R. S., Life after death: reverse logistics and the product life cycle. Int. J. Phys. Distrib. \& Logist. Manage., 2002, 32, 223-244.

Tibben-Lembke, R. S., Strategic use of the secondary market for retail consumer goods. California Manage. Rev., 2004, 46, 90-104.

Toffel, M. W., Strategic management of product recovery. California Manage. Rev., 2004, 46, 120-141.

Toffel, M. W., The growing strategic importance of end-of-life product management. California Manage. Rev., 2003, 45, 102-129.

Totkay, L. B., Wein, L. M. and Zenios, S. A., Inventory management of remanufacturable products. Manage. Sci., 2000, 46, 1412-1426.

Van der Laan, E. A. and Salomon, M., Production planning and inventory control with remanufacturing and disposal. Euro. J. Op. Res., 1997, 102, 264-278.

Van Der Laan, E. A., Dekker, R. and Salomon, M., Product remanufacturing and disposal: a numerical comparison of alternative control strategies. Int. J. Prod. Econ., 1996, 45, 489-498.

Van der Laan, E. A., Dekker, R., Salomon, M. and Ridder, A., An (s, Q) inventory model with remanufacturing and disposal. Int. J. Prod. Econ., 1996, 46-47, 339-350. 
Van der Laan, E. A., Salomon, M. and Dekker, R., An investigation of lead time effects in manufacturing/remanufacturing systems under simple PUSH and PULL control strategies. Euro. J. Op. Res., 1999, 115, 195-214.

Van der Laan, E. A., Salomon, M., Dekker, R. and Van Wassenhove, L. N., Inventory control in hybrid systems with remanufacturing. Manage. Sci., 1999, 45, 733-747.

Van Nunen, J. A. E. E. and Zuidwijk, R. A., E-enabled closed-loop supply chains. California Manage. Rev., 2004, 46, 40-54.

Vlachos, D. and Dekker, R., Return handling options and order quantities for single period products. Euro. J. Op. Res., 2003, 151, 38-52.

Vlachos, D. and Tagaras, G., An inventory system with two supply modes and capacity constraints. Int. J. Prod. Econ., 2001, 72, 41-58.

Voutsinas, T. G. and Pappis, C. P., Scheduling jobs with values exponentially deteriorating over time. Int. J. Prod. Econ., 2002, 79, 163-169.

Walther G. and Spengler, T. Impact of WEEE-directive on reverse logistics in Germany. Int. J. Phys. Distrib. \& Logist. Manage.,2005, 35, 337-361.

Yalabik, B., Petruzzi, N. C. and Chhajed, D., An integrated product returns model with logistics and marketing coordination. Euro. J. Op. Res., 2005, 161, 162-182.

Yang, J. Golany, B. and Gang, Y., A Concave-Cost Production Planning Problem with Remanufacturing Options. Naval Research Logistics, 2005, 52, 443-458.

Yao, Z., Wu, Y. And Lai, K. K., Demand uncertainty and manufacturer returns policies for style-good retailing competition. Prod. Planning \& Control, 2005, 16, 691-700.

Yuan, X. M. and Cheung, K. L., Modelling returns of merchandise in a inventory system. OR Spectrum, 1998, 20, 147-154. 